\title{
PERBEDAAN PEMBERIAN ASI EKSLUSIF DENGAN YANG TIDAK EKSLUSIF TERHADAP PERTUMBUHAN PADA BALITA DI UPTD PUSKESMAS KRANGKENG KABUPATEN INDRAMAYU
}

\author{
Iis, Ela Rohaeni
}

Sekolah Tinggi Ilmu Kesehatan (STIKes) Cirebon Jawa Barat, Indonesia

Email: iistehiis88@gmail.com, elarohaeni21@gmail.com

\begin{abstract}
Abstrak
Air Susu Ibu (ASI) Ekslusif yang diberikan kepada bayi semenjak dilahirkan sampai dengan usia 6 (enam) bulan adalah asupan makanan yang paling baik karena dalam ASI mengandung kolostrum yang kaya akan antibodi. Antibodi mengandung banyak protein untuk daya tahan tubuh dan bermanfaat untuk mematikan kuman dalam jumlah tinggi, sehingga pemberian ASI eksklusif dapat mengurangi risiko kematian pada bayi. Tujuan penelitian untuk mengetahui perbedaan pemberian ASI Eksklusif dengan yang tidak Eksklusif terhadap pertumbuhan pada balita di UPTD Puskesmas Krangkeng Kabupaten Indramayu. Penelitian ini menggunakan penelitian kuantitatif dengan pendekatan komparatif korelasional. Pengumpulan data dilakukan dengan menggunakan kuesioner. Populasi dalam penelitian ini adalah Seluruh balita di UPTD Puskesmas Krangkeng Kabupaten Indramayu sebanyak 4.029 balita. Sampel yang diambil berjumlah 38 orang dengan menggunakan teknik purposive sampling. Berdasarkan hasil penelitian didapatkan hasil sebagai berikut: 1) Rata-rata pertumbuhan pada balita yang tidak diberi ASI eksklusif adalah 8,96 dan mediannya 8,75 dengan standar deviasinya 1,447. Pertumbuhan paling rendah 7,0 dan paling tinggi 13,0. Berdasarkan nilai 95\% CI, diketahui bahwa pertumbuhan balita pada kelompok yang tidak diberi ASI eksklusif berkisar antara 8,14-9,80. Sedangkan rata-rata pertumbuhan pada balita yang diberi ASI eksklusif adalah 11,7 dan mediannya 10,5 dengan standar deviasinya 8,042. Pertumbuhan paling rendah 10,51 dan paling tinggi 12,91. Berdasarkan nilai 95\% CI, diketahui bahwa pertumbuhan balita pada kelompok yang diberi ASI eksklusif berkisar antara 10,51-12,91. 2) Rata-rata pertumbuhan pada balita yang tidak diberi ASI eksklusif adalah 8,96, sedangkan rata-rata pertumbuhan pada balita yang diberi ASI eksklusif adalah 11,7, hal ini berarti ada perbedaan sebesar 2,74.
\end{abstract}

Kata Kunci: asi ekslusif; pertumbuhan; balita

\section{Abstract}

Exclusive breast milk given to babies from birth to the age of 6 (six) months is the best food intake because breast milk contains colostrum rich in antibodies. Antibodies contain a lot of protein for endurance and are beneficial for turning off germs in high quantities, so exclusive breastfeeding can reduce the risk of death in infants. The purpose of the study was to find out the difference between exclusive

$\begin{array}{ll}\text { How to cite: } & \text { Iis. Ela Rohaeni (2021) Perbedaan Pemberian ASI Ekslusif Dengan Yang Tidak Ekslusif Terhadap } \\ & \text { Pertumbuhan Pada Balita Di UPTD Puskesmas Krangkeng Kabupaten Indramayu. Syntax Literate: } \\ & \text { Jurnal Ilmiah Indonesia. 6(7). http://dx.doi.org/10.36418/syntax-literate.v6i7.3643 } \\ \text { E-ISSN: } & \text { 2548-1398 } \\ \text { Published by: } & \text { Ridwan Institute }\end{array}$


breastfeeding and non-exclusive growth in toddlers in UPTD Krangkeng Health Center in Indramayu Regency. This study uses quantitative research with a comparative correlational approach. Data collection is done using questionnaires. The population in this study is all toddlers in uptd Krangkeng Health Center Indramayu regency as many as 4,029 toddlers. The samples were taken by 38 people using purposive sampling techniques. Based on the results of the study obtained the following results: 1) The average growth in toddlers who are not breastfed exclusively is 8.96 and the median is 8.75 with a standard deviation of 1,447. Growth was at least 7.0 and as high as 13.0. Based on the value of $95 \%$ CI, it is known that the growth of toddlers in the group that is not breastfed exclusively ranges from 8.14-9.80. While the average growth in toddlers who are breastfed exclusively is 11.7 and the median is 10.5 with a standard deviation of 8,042. Growth was at least 10.51 and the highest was 12.91. Based on the value of $95 \%$ CI, it is known that the growth of toddlers in the exclusively breastfed group ranges from 10.51-12.91. 2) The average growth in toddlers who were not exclusively breastfed was 8.96, while the average growth in toddlers who were given exclusive breast milk was 11.7, this meant there was a difference of 2.74 .

Keywords: exclusive breastfeeding; growth; toddler

\section{Pendahuluan}

Pengukuran status gizi didasarkan atas Standar World Health Organization (WHO, 2015) yang sudah diresmikan pada Keputusan Menteri Kesehatan No 1995/Menkes/SK/XII/2010 tentang Standar Antropometri Penilaian Status Gizi Anak. Bagi standar tersebut, status gizi bayi bisa diukur bersumber pada 3 indeks, ialah berat tubuh bagi usia $(\mathrm{BB} / \mathrm{U})$, besar tubuh bagi usia $(\mathrm{TB} / \mathrm{U})$, serta berat tubuh bagi besar tubuh(BB/TB) (Kemenkes, 2016).

Makanan satu-satunya yang terbaik untuk bayi adalah Air Susu Ibu (ASI), karena komposisi gizi yang terkandung dalam ASI merupakan komposisi yang paling lengkap untuk proses pertumbuhan dan perkembangan bayi (Sugiarti, Zulaekah, \& Puspowati, 2018). Hingga beberapa bulan setelah lahir, bayi belum memiliki sistem pertahanan tubuh yang lengkap, sehingga bayi yang diberi ASI jarang sakit, karena ASI mengandung zat kekebalan yang tidak dimiliki bayi (Rahmadhani, Lubis, \& Edison, 2013).

Gizi kurang baik merupakan status gizi bersumber pada indeks massa tubuh (BB/B) bersumber pada umur. Menurut Studi Kesehatan Dasar (Riskesdas) 2018 yang diselenggarakan Departemen Kesehatan, proporsi anak umur 0- 23 bulan di Indonesia hadapi gizi kurang sebesar 3, 8\%, serta gizi kurang sebesar 11,4\%. Hal ini tidak jauh berbeda dengan hasil Pemantauan Status Gizi (PSG) yang diselenggarakan oleh Kementerian Kesehatan tahun 2017, yaitu angka gizi buruk anak usia 0-23 bulan sebesar 3,5\%, dan angka gizi kurang 11,3\%.

Provinsi dengan angka gizi buruk anak 0-23 bulan tertinggi pada tahun 2018 adalah Nusa Tenggara Timur, sedangkan provinsi dengan angka terendah adalah Jawa Barat (Kemenkes, 2016).

Sedangkan di Kabupaten Indramayu pada tahun 2018, jumlah balita yang 
ditimbang 83.525 balita dan yang mengalami gangguan pertumbuhan sebanyak 1.033 balita $(1,24 \%)$. Adapun puskesmas dengan presentase balita yang mengalami gangguan pertumbuhan paling tinggi adalah UPTD Puskesmas Krangkeng yaitu sebanyak 183 balita $(4,54 \%)$ dari 4.029 balita yang ditimbang. Sedangkan jumlah anak yang diberi ASI eksklusif di UPTD Puskesmas Krangkeng pada tahun 2018 sebanyak 749 anak (18,5\%) (Dinas Kesehatan Kabupaten Indramayu, 2019).

Menurut (Rachmaniah, 2014) sebagian aspek yang pengaruhi pemberian ASI eksklusif Meliputi: aspek sosial budaya, pembelajaran resmi bunda, status pekerjaan Bunda, aspek psikologis (khawatir kehabisan kewanitaan, tekanan mental), aspek raga bunda (bunda yang sakit, semacam mastitis, penciptaan ASI menurun, kesusahan mengisap balita, puting bunda tidak tertopang dll), pembatasan tenaga kesehatan, pengaruh iklan ataupun Promosi pengganti ASI, serta aspek pengetahuan bunda. Penelitian (Rachmaniah, 2014) menjelaskan bahwa pengetahuan Ibu terhadap pentingnya pemberian ASI untuk bayi itu menjadi faktor yang sangat berpengaruh akan kesadaran orang tua/Ibu untuk memberikan ASI Ekslusif untuk bayi, ini ditunjukan bakal terjadi kenaikan pemberian ASI Eksklusif seandainya diiringi dengan kenaikan pengetahuan tentang ASI Eksklusif. Bagi (Firmansyah, 2012) memaparkan kalau 75, 6\% ibu yang tidak memberikan ASI Eksklusif ialah ibu dengan pendidikan tamat SD, dan berstatus sebagai pekerja lepas maupun buruh (Firmansyah, 2012).

Kabupaten Indramayu pada tahun 2018, jumlah balita yang ditimbang 83.525 balita dan yang mengalami gangguan pertumbuhan sebanyak 1.033 balita $(1,24 \%)$. Adapun puskesmas dengan presentase balita yang mengalami gangguan pertumbuhan paling tinggi adalah UPTD Puskesmas Krangkeng yaitu sebanyak 183 balita $(4,54 \%)$ dari 4.029 balita yang ditimbang. Sedangkan jumlah anak yang diberi ASI eksklusif di UPTD Puskesmas Krangkeng pada tahun 2018 sebanyak 749 anak (18,5\%) (Dinas Kesehatan Kabupaten Indramayu, 2019).

Hasil studi pendahuluan yang dilakukan penelitian di UPTD Puskesmas krangkeng Kabupaten Indramayu terhadap 10 ibu yang mempunyai balita usia 7-60 bulan, didapatkan sebanyak 7 ibu mengatakan anaknya tidak diberi ASI sampai usia 6 bulan dikarenakan faktor kesibukan dan ASI yang keluar sedikit, sedangkan sisanya 3 ibu lainnya mengatakan tidak ada masalah dengan ASI dan anaknya mendapatkan ASI sampai usia 6 bulan. Disamping itu, juga didapatkan sebanyak 2 dari 7 balita yang tidak mendapatkan ASI mengalami penurunan garis pertumbuhan di bawah normal.

Berdasarkan uraian tersebut, maka penulis tertarik untuk melakukan penelitian tentang "Perbedaan Pemberian ASI Eksklusif dengan yang tidak Eksklusif terhadap pertumbuhan pada balita di UPTD Puskesmas Krangkeng Kabupaten Indramayu tahun 2019”

\section{Metode Penelitian}

\section{A. Waktu dan Tempat Penelitian}

Penelitian ini menggunakan penelitian kuantitatif dengan pendekatan komparatif korelasional (Cresswell, 2017). Komparatif korelasional dalam 
penelitian ini untuk mengetahui perbedaan pemberian ASI Eksklusif dengan yang tidak Eksklusif terhadap pertumbuhan pada balita.

a. Tempat Penelitian

Tempat yang digunakan dalam penelitian ini adalah di UPTD Puskesmas Krangkeng Kabupaten Indramayu.

b. Waktu Penelitian

Penelitian telah dilaksanakan Juni 2019

\section{B. Teknik Pengumpulan Data}

1. Populasi Penelitian

Populasi dalam penelitian adalah wilayah yang akan dijadikan objek kajian dalam penelitian. Populasi juga merupakan bagian secara umum dari obyek atau subyek yang memilki karakteristik dan kualitas tertentu yang sudah ditentukan peneliti kemudian untuk dipelajari dan ditarik kesimpulanya.

Populasi dalam penelitian ini adalah seluruh balita di UPTD Puskesmas Krangkeng Kabupaten Indramayu sebanyak 4.029 balita.

2. Sampel Penelitian

Sampel adalah objek yang diteliti dan dianggap mewakili populasi (Notoadmodjo S, 2010). Sampel pada penelitian ini adalah balita di UPTD Puskesmas Krangkeng Kabupaten Indramayu dan tidak sedang sakit sebanyak 38 orang terdiri dari 19 orang untuk kelompok yang diberi ASI eksklusif dan 19 orang untuk kelompok yang diberi ASI tidak eksklusif.

\section{Hasil dan Pembahasan}

\section{A. Hasil Penelitian}

1. Analisis Univariat

Tabel 1

Distribusi Pertumbuhan pada Balita yang Diberi ASI Eksklusif dan Tidak ASI Eksklusif pada Balita di UPTD Puskesmas Krangkeng

\begin{tabular}{ccccc}
\hline $\begin{array}{c}\text { Pertumbuhan } \\
\text { Balita }\end{array}$ & $\begin{array}{c}\text { Mean- } \\
\text { Median }\end{array}$ & S.D & $\begin{array}{c}\text { Minimal- } \\
\text { Maksimal }\end{array}$ & 95\% CI \\
\hline Tidak ASI & 8,96 & 1,447 & $7,0-13,0$ & $8,14-9,80$ \\
eksklusif & 8,75 & & & \\
\hline ASI eksklusif & 11,7 & 8,042 & $10,51-$ & $10,51-$ \\
& 10,5 & & 12,91 & 12,91 \\
\hline
\end{tabular}

Berdasarkan Tabel 1 dapat diketahui bahwa rata-rata pertumbuhan pada balita yang tidak diberi ASI eksklusif adalah 8,96 dan mediannya 8,75 dengan standar deviasinya 1,447. Pertumbuhan paling rendah 7,0 dan paling tinggi 13,0. Berdasarkan nilai 95\% CI, diketahui bahwa pertumbuhan balita pada kelompok yang tidak diberi ASI eksklusif berkisar antara 8,14-9,80. Sedangkan rata-rata pertumbuhan pada balita yang diberi ASI eksklusif adalah 11,7 dan mediannya 10,5 dengan standar deviasinya 8,042. Pertumbuhan paling rendah 10,51 dan 
paling tinggi 12,91. Berdasarkan nilai 95\% CI, diketahui bahwa pertumbuhan balita pada kelompok yang diberi ASI eksklusif berkisar antara 10,51-12,91.

\section{Analisis Bivariat}

Tabel 2

Perbedaan Pemberian ASI Eksklusif dengan yang tidak Eksklusif terhadap Pertumbuhan pada Balita di UPTD Puskesmas Krangkeng

\begin{tabular}{ccccccc}
\hline $\begin{array}{c}\text { Pertumbuhan } \\
\text { Balita }\end{array}$ & N & Mean & $\begin{array}{c}\text { Beda } \\
\text { Mean }\end{array}$ & $\begin{array}{c}\text { Std. } \\
\text { Deviation }\end{array}$ & P value \\
\hline Tidak eksklusif & 14 & 8.96 & & 2.74 & $\frac{1.447}{2}$ & 0.002 \\
\hline Eksklusif & 24 & 11.71 & & 2.836 & \\
\hline
\end{tabular}

Berdasarkan Tabel 2, Menunjukkan bahwa rata-rata pertumbuhan pada balita yang tidak diberi ASI eksklusif adalah 8,96, sedangkan rata-rata pertumbuhan pada balita yang diberi ASI eksklusif adalah 11,7, hal ini berarti ada perbedaan sebesar 2,74. Perbedaan ini menunjukkan perbedaan yang bermakna yang terlihat dari hasil uji $\mathrm{t}$ independen pada $\alpha=0,05$ diperoleh nilai $\mathrm{p}$ $=0,002$ yang artinya nilai $\mathrm{p}<0,05$ dengan demikian maka terdapat perbedaan pemberian ASI Eksklusif dengan yang tidak Eksklusif terhadap pertumbuhan pada balita di UPTD Puskesmas Krangkeng.

\section{B. Pembahasan}

1. Gambaran Pertumbuhan pada Balita yang diberi ASI Eksklusif dan Tidak ASI Eksklusif pada Balita di UPTD Puskesmas Krangkeng

Berdasarkan hasil penelitian, menunjukkan bahwa rata-rata pertumbuhan pada balita yang tidak diberi ASI eksklusif adalah 8,96, sedangkan rata-rata pertumbuhan pada balita yang diberi ASI eksklusif adalah 11,7, hal ini berarti ada perbedaan sebesar 2,74. Pertumbuhan pada balita dapat dikarenakan kebutuhan gizi pada saat usia 0-6 belum terpenuhi dengan baik, sehingga anak yang tidak mendapatian ASI secara eksklusif pertumbuhannya akan terhambat. Pada penelitian ini juga didapatkan bahwa beberapa anak walaupun mendapatkan ASI eksklusif namun pertumbuhannya tidak normal, hal ini dapat dimungkinkan karena adanya faktor lain seperti lingkungan atau pola asuh orang tua yang kurang memperhatikan pertumbuhan anaknya.

Air Susu Ibu (ASI) dalam istilah kesehatan adalah dimulai dari proses laktasi. ASI merupakan emulsi lemak dalam larutan protein, laktose dan garam organik yang disekresi oleh kedua belah kelanjar payudara dari seorang ibu, dan ASI merupakan makanan utama bagi bayi (Natalia, 2021). ASI ialah asupan makanan yang sangat sesuai untuk balita untuk memenuhi kebutuhan gizi serta melindunginya dalam melawan serangan dari berbagai penyakit. Balita yang usianya sampai 6 bulan, ASI dapat mencukupi kebutuhan karbohidrat, lemak, protein, vit, serta antibodi yang tidak dimiliki oleh susu dari merek apapun (Utami Roesli, 2012). 
World Health Organization (WHO) merekomendasikan para oran tua buat menyusui secara eksklusif selama 6 bulan lamanya, melanjutkannya dengan pemberian makanan pendamping ASI dari bahan-bahan lokal yang kaya akan nutrisi sembari senantiasa tetap memberikan ASI ataupun menyusui hingga anak berumur 2 tahun lebih. Balita yang tidak memperoleh ASI sepanjang 6 bulan bisa menyebabkan balita lebih gampang terkena bermacam berbagai peradangan, penyakit bahkan menimbulkan kematian (Kementrian kesehatan RI, 2018). Menurut WHO dalam (U Roesli, 2015) pengaruh akibat tidak diberi ASI secara eksklusif, maka bayi kebanyakan akan mudah-mudah diserang berbagai penyakit antara lain: asma, alergi, infeksi saluran pernapasan akut, kurang gizi, bahkan dapat meningkatkan resiko kematian pada bayi dan akan anak.

Pada penelitian ini masih terdapat balita yang pertumbuhannya tidak normal, maka dari itu petugas kesehatan perlu meningkatkan penyuluhan tentang ASI Eksklusif kepada ibu, memotivasi ibu untuk mengkonsumsi makanan yang dapat meningkatkan produksi ASI seperti sayur daun katuk, dan juga memotivasi ibu untuk selalu melakukan kontak atau berkonsultasi dengan petugas kesehatan untuk mendapatkan informasi tentang ASI dan juga tentang stimulus pertumbuhan pada anak. Bagi ibu untuk lebih rajin mencari informasi tentang ASI eksklusif agar memahami dengan baik dan benar.

2. Perbedaan Pemberian ASI Eksklusif dengan yang tidak Eksklusif terhadap Pertumbuhan pada Balita di UPTD Puskesmas Krangkeng

Berdasarkan penelitian diperoleh bahwa terdapat perbedaan pemberian ASI Eksklusif dengan yang tidak Eksklusif terhadap pertumbuhan pada balita di UPTD Puskesmas Krangkeng Kabupaten Indramayu tahun 2019. Adanya perbedaan hal ini dikarenakan balita yang mendapatkan ASI secara eksklusif kebutuhan gizinya akan terpenuhi sehingga pertumbuhannya normal dan sebaliknya, balita yang tidak mendapatkan ASI eksklusif tentunya pertumbuhannya akan terhambat.

Hasil penelitian ini sejalan dengan teori bahwa pertumbuhan pada balita dapat disebabkan oleh beberapa faktor. Menurut (Soetjiningsih, 2015), pertumbuhan pada balita dapat dipengaruhi oleh penyebab langsung dan penyebab tidak langsung. Penyebab langsung yaitu kecukupan gizi (asupan makanan) dan status infeksi/ penyakit, sedangkan penyebab tidak langsungnya yaitu ketersediaan bahan pangan, sosial ekonomi, pola asuh, pemberian ASI, pemberian MPASI, kehamilan remaja, jarak kelahiran yang dekat, kebersihan dan sanitasi, pelayanan kesehatan dan lingkungan.

Hasil riset ini sejalan dengan teori perkembangan pada bayi paling utama sebagian besar ditetetapkan oleh jumlah ASI yang diperoleh, tercantum tenaga serta zat gizi yang lain yang tercantum di dalam ASI tersebut. ASI tanpa bahan santapan lain bisa memadai kebutuhan perkembangan umur mulai dari 6 bulan sampai 2 tahun. Pemberian ASI tanpa pemberian asupan lain selama 6 bulan tersebut dengan menyusui secara eksklusif. ASI memiliki berbagai manfaat yang 
baik untuk pertumbuhan anak juga dapat menurunkan risiko terjadinya penyakit akut dan kronik (Utami Roesli, 2012).

Hasil penelitian ini sejalan dengan teori bahwa ASI ini sangat penting bagi pertumbuhan. Untuk mencapai pertumbuhan anak yang optimal maka ASI hendaknya diberikan secara eksklusif yaitu pemberian ASI tanpa makanan atau cairan lain sampai 6 bulan dan dapat dilanjutkan hingga 2 tahun dengan tambahan makanan lainnya (Kementrian kesehatan RI, 2018). ASI yang tidak eksklusif akan menyebabkan anak akan mudah terserang infeksi saluran pernapasan atas (ISPA), diare, dan penyakit usus parah dan pada ibu dapat meningkatkan risiko kanker payudara (U Roesli, 2015).

Penelitian ini sangat jelas menerangkan bahwa adanya perbedaan pada pemberian ASI yang Eksklusif dengan pemberian ASI yang tidak Eksklusif terhadap pertumbuhan bayi, oleh karena dari itu dinas kesehatan perlu mengadakan penyuluhan tentang ASI Eksklusif kepada ibu-ibu dengan strategi dan langkah yang mudah untuk dipahami, memberikan memotivasi kepada ibuibu agar berupaya untuk memberikan ASI secara eksklusif walaupun ibu-ibu sibuk bekerja karena ada cara untuk menyimpan ASI dengan baik. Bagi ibu untuk lebih rajin mencari informasi tentang ASI eksklusif agar memahami dengan baik dan benar dan juga mengkonsumsi makanan yang dapat meningkatkan produksi ASI seperti daun katuk dan lain sebagainya.

\section{Kesimpulan}

Sesuai hasil penelitian dan kajian pembahasan sebelumnya tentang perbedaan pemberian ASI Eksklusif dengan yang tidak Eksklusif terhadap pertumbuhan pada balita di UPTD Puskesmas Krangkeng Kabupaten Indramayu tahun 2019, maka dapat diambil kesimpulan sebagai berikut: 1). Rata-rata pertumbuhan pada balita yang tidak diberi ASI eksklusif di UPTD Puskesmas Krangkeng Kabupaten Indramayu tahun 2019 adalah 8,96, sedangkan rata-rata pertumbuhan pada balita yang diberi ASI eksklusif adalah 11,7. 2). Terdapat perbedaan pemberian ASI Eksklusif dengan yang tidak Eksklusif terhadap pertumbuhan pada balita di UPTD Puskesmas Krangkeng. 
Perbedaan Pemberian ASI Ekslusif dengan yang tidak Ekslusif Terhadap Pertumbuhan pada Balita Di UPTD Puskesmas Krangkeng Kabupaten Indramayu

\section{BIBLIOGRAFI}

Cresswell, J. W. (2017). Research Design: Pendekatan Kualitatif, Kuantitatif, dan Mixed (Edisi Ketiga). Yogyakarta: Pustaka Belajar. Google Scholar

Dinas Kesehatan Kabupaten Indramayu. (2019). Jumlah anak yang diberi ASI eksklusif di UPTD Puskesmas Krangkeng pada tahun 2018 sebanyak 749 anak (18,5\%). Indramayu: Dinas Kesehatan Kabupaten Indramayu.

Firmansyah, Nurhuda. (2012). Pengaruh Karakteristik (Pendidikan, Pekerjaan), Pengetahuan dan Sikap Ibu Menyusui terhadap Pemberian Asi Eksklusif di Kabupaten Tuban. Universitas Airlangga. Google Scholar

Kemenkes, R. I. (2016). Profl Kesehatan RI Tahun 2016. Jakarta, Kementrian Kesehatan RI.

Kementrian kesehatan RI. (2018). Hasil utama riskesdas 2018. 61.

Natalia, Kristin. (2021). Efektivitas Daun Katuk (Sauropus Androgynus) Terhadap Kecukupan Asi Pada Ibu Menyusui Dimasa Pandemi Covid-19. Jurnal Penelitian Kebidanan \& Kespro, 3(2), 1-6. Google Scholar

Notoadmodjo S. (2010). Metodelogi Penelitian Kesehatan. Jakarta: Rineka Cipta.

Rachmaniah, Nova. (2014). Hubungan tingkat pengetahuan ibu tentang ASI dengan tindakan ASI Eksklusif. Universitas Muhammadiyah Surakarta. Google Scholar

Rahmadhani, Eka Putri, Lubis, Gustina, \& Edison, Edison. (2013). Hubungan pemberian ASI eksklusif dengan angka kejadian diare akut pada bayi usia 0-1 tahun di Puskesmas Kuranji Kota Padang. Jurnal Kesehatan Andalas, 2(2), 62-66. Google Scholar

Roesli, U. (2015). Panduan Inisiasi Menyusu Dini Plus ASI Eksklusif. Jakarta: Jakarta: Pustaka Bunda. Google Scholar

Roesli, Utami. (2012). Panduan Inisiasi Menyusu Dini; plus ASI eksklusif. Jakarta: Pustaka Bunda. Google Scholar

Soetjiningsih. (2015). ASI petunjuk Tenaga Kesehatan. Jakarta: EGC.

Sugiarti, Eni, Zulaekah, Siti, \& Puspowati, Dyah. (2018). Faktor - faktor yang berhubungan dengan pemberian asi eksklusif di kecamatan karangmalang kabupaten sragen. Jurnal Kesehatan, 4(2), 195-206. Google Scholar

WHO. (2015). World Health Statistic Report 2015. Geneva: World Health Organization; 2015. Google Scholar

\section{Copyright holder:}


Iis, Ela Rohaeni

Iis, Ela Rohaeni (2021)

First publication right:

Syntax Literate: Jurnal Ilmiah Indoensia

This article is licensed under:

(c) (i) (O) 